\title{
Synthesis and Characterization of Cage and Bicyclic Silsesquioxanes via Dehydration of Silanols
}

\author{
Masafumi Unno, Shamsul Bahri Alias, Miwako Arai, Keisuke Takada, \\ Ryoji Tanaka and Hideyuki Matsumoto* \\ Department of Applied Chemistry, Faculty of Engineering, Gunma University, Kiryu, Gunma 376-8515, \\ Japan
}

Synthesis of cage and ladder silsesquioxanes by the dehydration of silanols using dicyclohexylcarbodiimide (DCC) is described. The reaction of 1,3-dicyclohexyldisiloxane-1,1,3,3-tetraol with DCC gave octa(cyclohexylsilsesquioxane) in $13 \%$ yield. The bicyclic ladder siloxane 3 $\left(\mathrm{Ph}_{8} \mathrm{Thex}_{2} \mathrm{Si}_{6} \mathrm{O}_{7}\right)$ was prepared from 1,1,3,3tetraphenyldisiloxane-1,3-diol and 1,3-dithexyldisiloxane-1,1,3,3-tetraol (Thex or thexyl denotes 1,1,2-trimethylpropy) at $80^{\circ} \mathrm{C}$. In this reaction, the propellane-type cage siloxane 2 $\left(\mathrm{Ph}_{6} \mathrm{Thex}_{2} \mathrm{Si}_{5} \mathrm{O}_{6}\right)$ was generated also. Upon reaction completion at $120^{\circ} \mathrm{C}$, only 2 was obtained. The reaction from the same starting compounds with diisopropylcarbodiimide at $80{ }^{\circ} \mathrm{C}$ resulted in another caged siloxane, $\mathrm{Ph}_{4} \mathrm{Thex}_{4} \mathrm{Si}_{6} \mathrm{O}_{8}(5)$. The structures of 2,3 and 5 were determined by $\mathrm{X}$-ray crystallography. Copyright (C) 1999 John Wiley \& Sons, Ltd.

Keywords: silsesquioxane; ladder polysiloxane; cage polysiloxane; $\mathrm{X}$-ray structure; silanol

\section{INTRODUCTION}

As a part of our investigation of the chemistry of polycyclic silicon compounds, ${ }^{1-3}$ we have been

* Correspondence to: Hideyuki Matsumoto, Department of Applied Chemistry, Faculty of Engineering, Gunma University, Kiryu, Gunma 376-8515, Japan.

E-mail: matumoto@chem.gunma-u.ac.jp

Contract/grant sponsor: Ministry of Education, Science and Culture, Japan.

Contract/grant sponsor: REIMEI Research of Japan Atomic Energy Research Institute. interested in the synthesis and characterization of polycyclic oligosiloxanes with well-defined structures. In a previous paper, we reported a new synthetic procedure for the preparation of cage siloxanes, hexa(thexylsilsesquioxane) (thexyl or Thex denotes 1,1,2-trimethylpropyl hereafter) and hexakis( $t$-butylsilsesquioxane) from the corresponding silanetriol or disiloxanetetraol, utilizing dicyclohexylcarbodiimide (DCC) as a dehydrating reagent (Scheme 1). ${ }^{4}$ This procedure requires slightly forced conditions, but the reaction was completed in a shorter time and resulted in higher

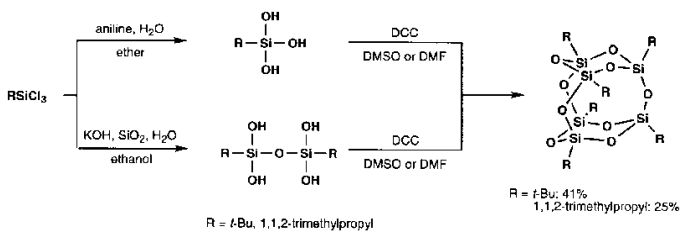

Scheme 1

yield than the hydrolysis of the corresponding organotrichlorosilanes.

Here we report the syntheses and structures of cage and bicyclic oligosiloxanes containing thexyl, phenyl and cyclohexyl groups using DCC.

\section{RESULTS AND DISCUSSION}

\section{Synthesis of octa (cyclohexyl- silsesquioxane)}

Octa(cyclohexylsilsesquioxane) was known in the literature, but in each case preparations were made by multistep syntheses, i.e. alkali-catalyzed siloxane cracking at $340-440{ }^{\circ} \mathrm{C}$ of the hydrolysis product of cyclohexyltrichlorosilane, ${ }^{5}$ hydrogena- 
tion of octa(phenylsilsesquioxane) ${ }^{6}$ or the reaction of 7,13-dihydroxytetracyclo[9.5.1.1 $1^{3,9} \cdot 1^{5,15}$ ]octasiloxane $\left[\mathrm{R}_{7} \mathrm{Si}_{7} \mathrm{O}_{9}(\mathrm{OH})_{3}\right]$, which was obtained by condensation of cyclohexyltrichlorosilane in aqueous acetone for four months using $\mathrm{RSiCl}_{3}$ $(\mathrm{R}=$ cyclohexyl $) .{ }^{7}$ When cyclohexyltrichlorosilane or cyclohexylsilanetriol was condensed in aqueous solution, the cage compound obtained was hexasilsesquioxane $\left(\mathrm{T}_{6}\right)$, and octasilsesquioxane $\left(\mathrm{T}_{8}\right)$ was not produced. ${ }^{8}$ Here we applied our method to a one-pot synthesis of octa(cyclohexylsilsesquioxane). The procedure is shown in Scheme 2. The starting 1,3-dicyclohexyldisiloxane-1,1,3,3-tetraol was prepared by the reported method, ${ }^{7}$ and after the reaction with DCC for three days at $120^{\circ} \mathrm{C}$ octasilsesquioxane 1 was obtained in $13 \%$ yield after separation by column chromatography (silica/ hexane). The other fractions were collected carefully; NMR and mass spectral results indicate these were all polymeric siloxanes. Compound 1 was identified by NMR and MS, and these spectra were identical to those in the literature. ${ }^{4}$

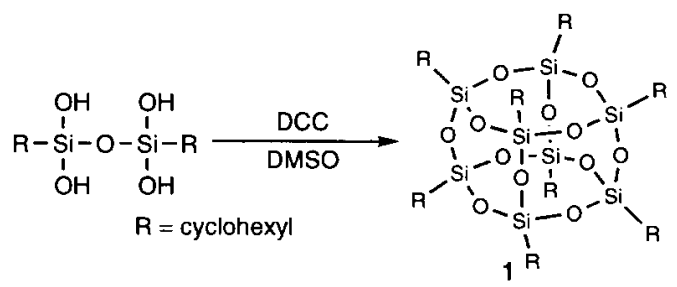

Scheme 2

\section{Synthesis of ladder silsesquioxane}

Ladder polysilsesquioxanes were first reported by Brown et al. in $1960 ;{ }^{9}$ however, their results were without structural evidence, and the real structure is still controversial. ${ }^{10}$ Until now, polysiloxanes containing ladder structures have been widely used as materials with improved properties, e.g. high thermal stability. ${ }^{10}$ In order to examine the synthesis and structure of ladder siloxanes, we prepared bicyclic oligosiloxane as a model system. Bicyclic oligosilsesquioxane $\left[\left(\mathrm{C}_{7} \mathrm{H}_{13}\right)_{6} \mathrm{Si}_{6} \mathrm{O}_{7}(\mathrm{OH})_{4}\right]$ has also been obtained in the condensation reaction from cycloheptytrichlorosilane ${ }^{11}$.

For the preparation of ladder polysilsesquioxanes, we have examined the condensation of 1,3dithexyldisiloxane-1,1,3,3-tetraol and 1,1,3,3-tetraphenyldisiloxane-1,3-diol with DCC. The reaction pathway is shown in Scheme 3. Preparation of 1,1,3,3-tetraphenyldisiloxane-1,3-diol ${ }^{12}$ and 1,3dithexyldisiloxane-1,1,3,3-tetraol ${ }^{4}$ was effected by following the reported methods. A 1:1 mixture of the tetraol and diol was heated with DCC at $80^{\circ} \mathrm{C}$ in dimethyl sulfoxide (DMSO). Analysis with HPLC indicated that $\mathbf{2}$ and $\mathbf{3}$ existed as isolable products which could be separated easily by reverse-phase recycle-type HPLC; yields were $24 \%$ for 2 and $17 \%$ for $\mathbf{3}$. For product $\mathbf{2}$, unfortunately a suitable crystal for X-ray analysis could not be obtained and the structure was confirmed by IR, mass and NMR $\left({ }^{1} \mathrm{H},{ }^{13} \mathrm{C},{ }^{29} \mathrm{Si}\right)$ spectroscopy. Mass spectra indicated a molecular weight of 868 , which was the evidence for a composition $\mathrm{Ph}_{6} \mathrm{Thex}_{2} \mathrm{Si}_{5} \mathrm{O}_{7}$. In ${ }^{1} \mathrm{H} \mathrm{NMR}$, the resonances for single thexyl and phenyl groups were observed, indicating the high symmetry of the structure. The integration ratio was $\mathrm{Thex} / \mathrm{Ph}=1: 3$. The result of ${ }^{13} \mathrm{C}$ NMR also supported this high symmetry (four peaks for the thexyl group, and four peaks for the phenyl group). In ${ }^{29} \mathrm{Si} \mathrm{NMR}$, two resonances were observed at -21.4 and -58.8 ppm, which means that the compound possesses one kind of T-type $\mathrm{RSiO}_{3}$ and one kind of D-type $\mathrm{R}_{2} \mathrm{SiO}_{2}$. From the $\overline{\mathrm{IR}}$ and ${ }^{1} \mathrm{H}$ NMR spectra, no $\mathrm{Si}-\mathrm{H}$ or $\mathrm{Si}-\mathrm{OH}$ groups existed. With these results, compound $\mathbf{2}$ was identified as 1,5-bis(1,1,2-trimethylpropyl)-3,3,7,7,10,10-hexaphenylbicyclo[3.3.3]pentasiloxane. Compound $\mathbf{3}$ was determined to be bicyclic ladder-type siloxane from spectral data as well as X-ray crystallography. It also showed two resonances in ${ }^{29} \mathrm{Si} \mathrm{NMR}$ at -24.4 and $-65.8 \mathrm{ppm}$, and all the other spectra satisfied the same structure.

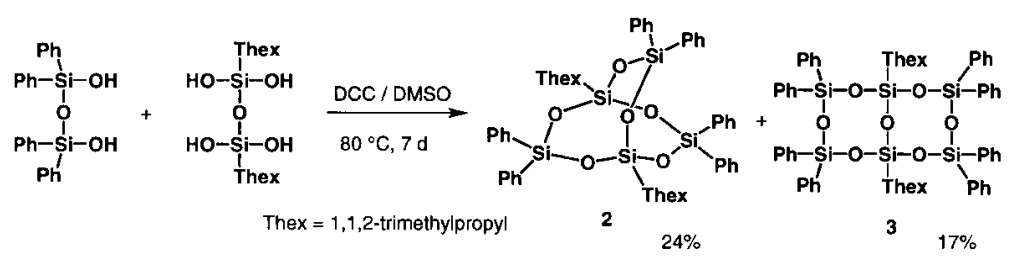

Scheme 3 


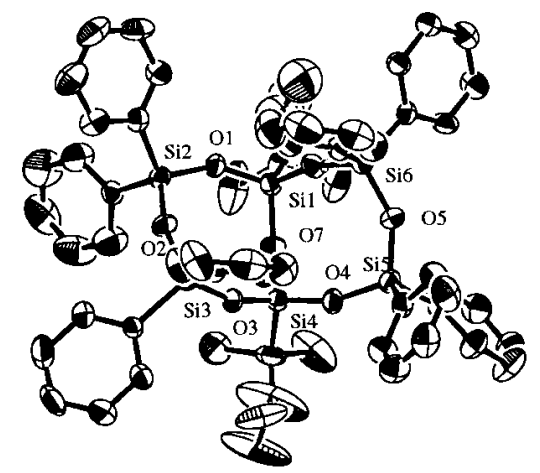

Figure 1 ORTEP drawing of $\mathbf{3}$. Thermal ellipsoids are drawn at the $30 \%$ probability level.

\section{Structure of bicyclic ladder siloxanes}

The crystal structure of $\mathbf{3}$ is shown in Fig. 1. The summary of crystal data, data collection and refinement is shown in Table 1; selected bond lengths and angles are shown in Table 2. In 1980, Shklover et al. reported the synthesis and structure of 3,3,5,5,9,9,11,11-octamethyl-1,7-diphenylbicyclo[5,5,1]hexasiloxane $\left(\mathrm{Me}_{6} \mathrm{Ph}_{2} \mathrm{Si}_{5} \mathrm{O}_{6}\right),{ }^{13}$ and our result is the second example of a bicyclic ladder polysiloxane.

In order to compare the structures of these two compounds more intensively, we prepared $\mathrm{Me}_{6} \mathrm{Ph}_{2}$ $\mathrm{Si}_{5} \mathrm{O}_{6}(4)$ using the method of Shklover et al. ${ }^{13}$ Thus the reaction of tetramethyldisiloxanediol and diphenyltetrachlorodisiloxane with diethylamine in benzene gave 4 in $22 \%$ yield (Scheme 4 ). In ${ }^{29} \mathrm{Si}$ NMR, two resonances were observed at -17.3 and

Table 1. X-ray diffraction analysis data for 3 and 4

\begin{tabular}{|c|c|c|}
\hline & $\mathrm{Thex}_{2} \mathrm{Ph}_{8} \mathrm{Si}_{6} \mathrm{O}_{7}, 3$ & $\mathrm{Ph}_{2} \mathrm{Me}_{8} \mathrm{Si}_{6} \mathrm{O}_{7}, 4$ \\
\hline \multicolumn{3}{|l|}{ Crystal data } \\
\hline Formula & $\mathrm{C}_{60} \mathrm{H}_{66} \mathrm{Si}_{6} \mathrm{O}_{7}$ & $\mathrm{C}_{20} \mathrm{H}_{34} \mathrm{Si}_{6} \mathrm{O}_{7}$ \\
\hline Mol wt & 1067.69 & 555.00 \\
\hline Crystal dimensions $\left(\mathrm{mm}^{3}\right)$ & $0.20 \times 0.20 \times 0.10$ & $0.40 \times 0.10 \times 0.10$ \\
\hline Crystal system & triclinic & monoclinic \\
\hline Space group & $P \overline{1}$ & $C 2 / c$ \\
\hline$a(\mathrm{~A})$ & $14.182(1)$ & $12.749(5)$ \\
\hline$b(\AA)$ & $20.149(3)$ & $14.967(7)$ \\
\hline$c(\AA)$ & $11.047(1)$ & $16.470(4)$ \\
\hline$\alpha(\operatorname{deg})$ & $97.49(1)$ & \\
\hline$\beta(\operatorname{deg})$ & $109.300(9)$ & $105.59(2)$ \\
\hline$\gamma(\operatorname{deg})$ & $81.690(10)$ & \\
\hline$V\left(\AA^{3}\right)$ & $2936.5(6)$ & $3026(1)$ \\
\hline$Z$ & 2 & 4 \\
\hline$d_{\text {calc }}\left(\mathrm{gcm}^{-3}\right)$ & 1.21 & 1.22 \\
\hline \multicolumn{3}{|l|}{ Data collection } \\
\hline Diffractometer & Rigaku AFC7S。 & Rigaku AFC7S。 \\
\hline Radiation & $\mathrm{Cu} \mathrm{K}{ }_{\alpha}(1.54178 \AA)$ & $\mathrm{Cu} \mathrm{K}_{\alpha}(1.54178 \AA)$ \\
\hline$\mu\left(\mathrm{cm}^{-1}\right)$ & 17.30 & 28.78 \\
\hline $2 \theta$ range $(\mathrm{deg})$ & $4-120.1$ & $4-120.1$ \\
\hline Scan type & $\omega-2 \theta$ & $\omega-2 \theta$ \\
\hline No. of refections measured & 9156 & 2463 \\
\hline No. of independent reflections & 8745 & 2341 \\
\hline No. of reflections observed & 3917 & 769 \\
\hline \multicolumn{3}{|l|}{$\left(\left|F_{0}\right| \geq 3 \sigma\left(F_{0}\right)\right)$} \\
\hline$R_{W}$ & 0.065 & 0.055 \\
\hline Weighting scheme & $w=4\left(F_{0}\right)^{2} / \sigma^{2}\left(F_{0}\right)^{2}$ & $w=4\left(F_{0}\right)^{2} / \sigma^{2}\left(F_{0}\right)^{2}$ \\
\hline$S$ & 2.57 & 2.50 \\
\hline$(\Delta / \sigma)_{\max }$ & 0.08 & 0.01 \\
\hline$(\Delta \rho)_{\max }^{\max }\left(\mathrm{e}^{-3}\right)$ & 0.92 & 0.26 \\
\hline$(\Delta \rho)_{\min }\left(\mathrm{e}^{-3}\right)$ & -0.68 & -0.25 \\
\hline No. of parameters & 639 & 150 \\
\hline
\end{tabular}


Table 2. Selected bond lengths ( $(\AA)$ and angles (deg) of 3

\begin{tabular}{lccc}
\hline Bond Lengths & & & \\
$\mathrm{Si}(1)-\mathrm{O}(1)$ & $1.608(5)$ & $\mathrm{Si}(1)-\mathrm{O}(6)$ & $1.615(7)$ \\
$\mathrm{Si}(1)-\mathrm{O}(7)$ & $1.614(7)$ & $\mathrm{Si}(2)-\mathrm{O}(1)$ & $1.618(7)$ \\
$\mathrm{Si}(2)-\mathrm{O}(2)$ & $1.615(8)$ & $\mathrm{Si}(3)-\mathrm{O}(2)$ & $1.618(7)$ \\
$\mathrm{Si}(3)-\mathrm{O}(3)$ & $1.613(6)$ & $\mathrm{Si}(4)-\mathrm{O}(3)$ & $1.602(6)$ \\
$\mathrm{Si}(4)-\mathrm{O}(4)$ & $1.615(6)$ & $\mathrm{Si}(4)-\mathrm{O}(7)$ & $1.618(7)$ \\
$\mathrm{Si}(5)-\mathrm{O}(4)$ & $1.626(7)$ & $\mathrm{Si}(5)-\mathrm{O}(5)$ & $1.625(8)$ \\
$\mathrm{Si}(6)-\mathrm{O}(5)$ & $1.620(6)$ & $\mathrm{Si}(6)-\mathrm{O}(6)$ & $1106(6)$ \\
Bond Angles & & & $110.6(3)$ \\
$\mathrm{O}(1)-\mathrm{Si}(1)-\mathrm{O}(6)$ & $107.2(3)$ & $\mathrm{O}(1)-\mathrm{Si}(1)-\mathrm{O}(7)$ & $109.0(3)$ \\
$\mathrm{O}(6)-\mathrm{Si}(1)-\mathrm{O}(7)$ & $107.5(3)$ & $\mathrm{O}(1)-\mathrm{Si}(2)-\mathrm{O}(2)$ & $108.8(4)$ \\
$\mathrm{O}(2)-\mathrm{Si}(3)-\mathrm{O}(3)$ & $109.4(4)$ & $\mathrm{O}(4)-\mathrm{Si}(4)-\mathrm{O}(4)$ & $108.7(4)$ \\
$\mathrm{O}(3)-\mathrm{Si}(4)-\mathrm{O}(7)$ & $108.0(3)$ & $\mathrm{O}(5)-\mathrm{Si}(6)-\mathrm{O}(6)$ & $156.7(4)$ \\
$\mathrm{O}(4)-\mathrm{Si}(5)-\mathrm{O}(5)$ & $110.4(3)$ & $\mathrm{Si}(2)-\mathrm{O}(2)-\mathrm{Si}(3)$ & $158.8(5)$ \\
$\mathrm{Si}(1)-\mathrm{O}(1)-\mathrm{Si}(2)$ & $151.4(5)$ & $\mathrm{Si}(4)-\mathrm{O}(4)-\mathrm{Si}(5)$ & $163.3(5)$ \\
$\mathrm{Si}(3)-\mathrm{O}(3)-\mathrm{Si}(4)$ & $160.0(5)$ & & \\
$\mathrm{Si}(5)-\mathrm{O}(5)-\mathrm{Si}(6)$ & $148.2(5)$ & & $\mathrm{Si}(6)$ \\
$\mathrm{Si}(1)-\mathrm{O}(7)-\mathrm{Si}(4)$ & $145.8(4)$ & & \\
\hline
\end{tabular}

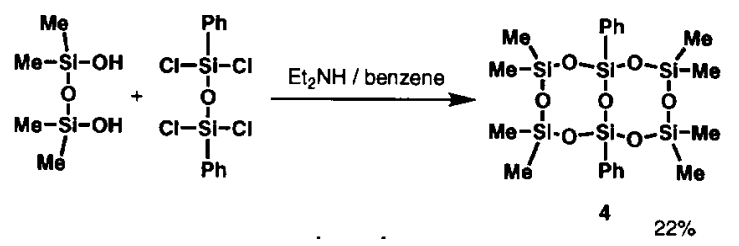

Scheme 4

$-76.4 \mathrm{ppm}$, and these values are in good agreement with those of $\mathbf{3}$, considering the difference between the substituents. The crystal structure of $\mathbf{4}$ is shown in Fig. 2; the summary of crystal data, data collection and refinement is shown in Table 1; selected bond lengths and angles are shown in Table 3. Shklover reported that $\mathbf{4}$ crystallized in the $P 2_{1} / c$ space group, and the molecule did not have a symmetry axis; however, in our case, the space

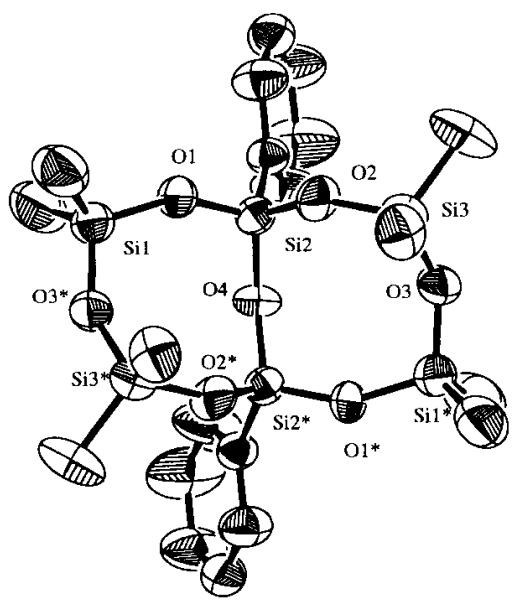

Figure 2 ORTEP drawing of $\mathbf{4}$. Thermal ellipsoids are drawn at the $30 \%$ probability level.

Table 3. Selected bond lengths ( $\AA$ ) and angles (deg) of 4

\begin{tabular}{lccc}
\hline $\begin{array}{l}\text { Bond Lengths } \\
\mathrm{Si}(1)-\mathrm{O}(1)\end{array}$ & $1.61(1)$ & $\mathrm{Si}(1)-\mathrm{O}\left(3^{*}\right)$ & $1.630(8)$ \\
$\mathrm{Si}(2)-\mathrm{O}(1)$ & $1.59(1)$ & $\mathrm{Si}(2)-\mathrm{O}(2)$ & $1.57(1)$ \\
$\mathrm{Si}(2)-\mathrm{O}(4)$ & $1.627(7)$ & $\mathrm{Si}(3)-\mathrm{O}(2)$ & $1.63(1)$ \\
$\mathrm{Si}(3)-\mathrm{O}(3)$ & $1.609(10)$ & & \\
Bond Angles & & & $106.3(6)$ \\
$\mathrm{O}(1)-\mathrm{Si}(1)-\mathrm{O}\left(3^{*}\right)$ & $109.7(5)$ & $\mathrm{O}(1)-\mathrm{Si}(2)-\mathrm{O}(2)$ & $112.2(5)$ \\
$\mathrm{O}(1)-\mathrm{Si}(2)-\mathrm{O}(4)$ & $110.5(4)$ & $\mathrm{O}(2)-\mathrm{Si}(2)-\mathrm{O}(4)$ & $147.8(6)$ \\
$\mathrm{O}(2)-\mathrm{Si}(3)-\mathrm{O}(3)$ & $110.9(6)$ & $\mathrm{Si}(1)-\mathrm{O}(1)-\mathrm{Si}(2)$ & $145.5(7)$ \\
$\mathrm{Si}(2)-\mathrm{O}(2)-\mathrm{Si}(3)$ & $146.1(7)$ & $\mathrm{Si}(3)-\mathrm{O}(3)-\mathrm{Si}\left(1^{*}\right)$ & \\
$\mathrm{Si}(2)-\mathrm{O}(4)-\mathrm{Si}\left(2^{*}\right)$ & $140.8(9)$ & & \\
\hline
\end{tabular}


group was identified as $C 2 / c$, and there is a symmetry axis through $\mathrm{O}(4)$. The structural parameters, including bond lengths and angles, were similar to each other.

As compound $\mathbf{3}$ has larger substituents, thexyl groups, the $\mathrm{Si}-\mathrm{O}-\mathrm{Si}$ angles were greater than those of 4 . Thus, the average $\mathrm{Si}-\mathrm{O}-\mathrm{Si}$ angles were $154.9^{\circ}$ for 3 and $145.1^{\circ}$ for 4 . On the other hand, the $\mathrm{Si}-\mathrm{O}$ bond lengths and $\mathrm{O}-\mathrm{Si}-\mathrm{O}$ angles were similar to each other; the average $\mathrm{Si}-\mathrm{O}$ bond lengths were $1.615 \AA$ for 3 and $1.61 \AA$ for 4 , and the average $\mathrm{O}-\mathrm{Si}-\mathrm{O}$ angles were $109.0^{\circ}$ for $\mathbf{3}$ and $109.9^{\circ}$ for $\mathbf{4}$. Interestingly, the $\mathrm{Si}-\mathrm{O}-\mathrm{Si}$ angles were very scattered for 3, 145.8(4)-163.3(5) . In the case of 4, scattering was not so great [140.8(9)-147.8(6)]; it seems that the relatively flexible $\mathrm{Si}-\mathrm{O}-\mathrm{Si}$ bond angle changed in order to release the steric repulsion of the substituents. In both compounds, two rings were in cis-fused orientation.

\section{Products under different reaction conditions}

To investigate the effect of temperature and dehydrating reagent, we then tried the condensation reaction of disiloxanediol and disiloxanetetraol at $120^{\circ} \mathrm{C}$, and with disopropylcarbodimide (DIC). The reactions are depicted in Scheme 5. When the same starting materials as in the case of $\mathbf{3}$ were stirred with DCC at $120^{\circ} \mathrm{C}$ for seven days the product was only $\mathbf{2}$, and no other products were isolated. The reaction from the same starting materials with DIC gave neither $\mathbf{2}$ nor $\mathbf{3}$, and the product was $\mathbf{5}$. The structure of $\mathbf{5}$ could be determined by the following spectral data: one kind each of thexyl and phenyl groups was observed in ${ }^{1} \mathrm{H}$ NMR, indicating a high symmetry of the molecule, as in the case of 2 . The $\mathrm{Ph} / \mathrm{Thex}$ ratio by integration was $1: 1$. In ${ }^{13} \mathrm{C} N \mathrm{NMR}$, similar

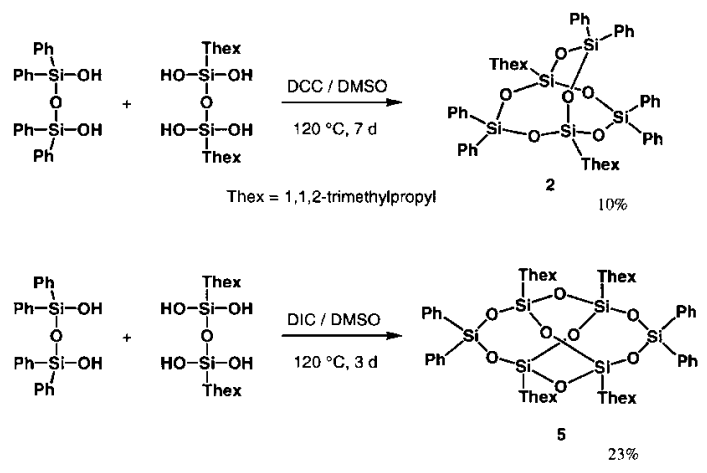

Scheme 5

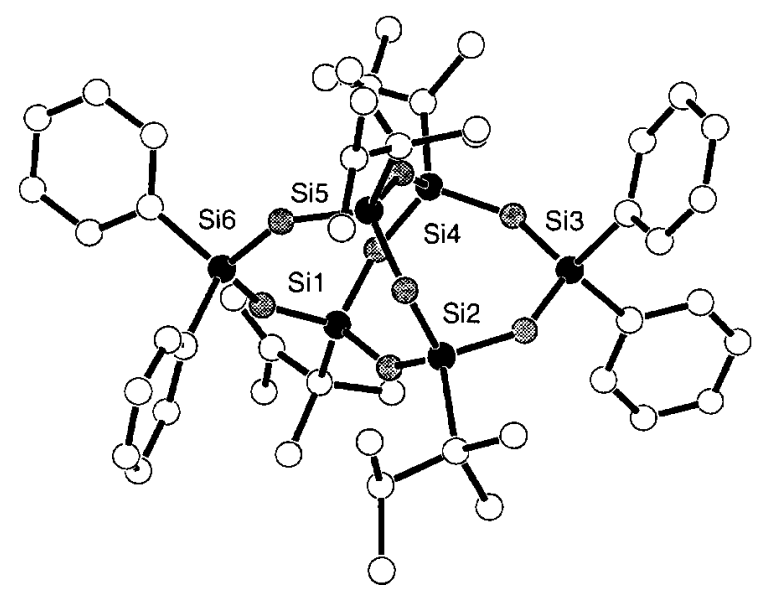

Figure 3 Molecular drawing of 5.

results were given; thus, four peaks for the thexyl $(\delta=18.53,20.59,24.18,34.12 \mathrm{ppm})$, and four peaks for the phenyl group (127.45, 129.80, $133.92,135.20 \mathrm{ppm})$. Two resonances $(-43.65$, $-60.40 \mathrm{ppm}$ ) were obtained in ${ }^{29} \mathrm{Si}$ NMR, and mass and IR spectra satisfied the structure 1,3,7,9tetrakis(1,1,2-trimethylpropyl)-5,5,11,11-tetraphenyltricyclo[5.5.1.1 ${ }^{3,9}$ ]hexasiloxane $\quad\left(\mathrm{Ph}_{4} \mathrm{Thex}_{4}\right.$ $\left.\mathrm{Si}_{6} \mathrm{O}_{8}\right)$. Preliminary results of X-ray crystallography established the structure of the framework [Fig. 3]: due to the severe disorder we could not determine the positions of substituents. Crystal data: monoclinic, $P 2_{1} / c, \quad{ } a=17.903(1) \mathrm{A}$, $b=14.552(1) \AA, \quad c=20.944(1) \AA, \quad V=5428.8(7)$ $\AA^{3}, \beta=95.752(6)^{\circ} Z=4, \mathrm{R}=0.110, R_{W}=0.102$ for 505 variables. These results show that the reaction conditions are important for the construction of the ladder structure, in addition to the selection of the substituents. So far as our investigations went, thexyl groups were rather large and preferred a twisted structure.

In summary, we extended the reaction using DCC to prepare octa(cyclohexylsilsesquioxane) and ladder-type siloxane, and the structures of some bicyclic ladder siloxanes were determined. In addition, the modification of the reaction gave different products, e.g. twisted siloxanes. Now we are investigating the application of different substituents to construct longer ladder siloxanes.

\section{EXPERIMENTAL}

NMR spectra were recorded on a JEOL Model $\alpha$ $500\left({ }^{1} \mathrm{H}, \quad 500.0 \mathrm{MHz} ;{ }^{13} \mathrm{C}, \quad 125.7 \mathrm{MHz} ;{ }^{29} \mathrm{Si}\right.$, 
99.3 MHz). Mass spectrometry was performed by JEOL JMS-D300. Infrared spectra were measured with a JASCO A-102 spectrometer. Analytical HPLC was performed with JASCO 875UV/880PU and UV-970/880PU equipment with Chemco $4.6 \mathrm{~mm} \times 250 \mathrm{~mm} 5$-ODS-H columns. Preparative recycle-type HPLC was performed on JAI LC-908 apparatus with Chemco $20 \times 250$ (w) 7-ODS-H columns.

\section{Synthesis of $1,3,5,7,9,11,13,15$ - octacyclohexylpentacyclo- $\left[9.5 .1 .1^{3,9} \cdot 1^{5,15} \cdot 1^{7,13}\right]$ octasiloxane (1)}

Dicyclohexyldisiloxanetetraol (1.00 g, $3.26 \mathrm{mmol})$, DCC (1.48 g, $7.18 \mathrm{mmol})$ and DMSO $(11 \mathrm{ml})$ were placed in a flask and the solution was heated at $120^{\circ} \mathrm{C}$. After three days the mixture was cooled to room temperature, and benzene $(16 \mathrm{ml})$ was added. The solid generated was filtered and the filtrate was washed with water $(40 \mathrm{ml})$, then the water phase was extracted with hexane three times ( $40 \mathrm{ml}$ each). The combined organic phase was dried and evaporated. The crude mixture obtained was purified by column chromatography (silica hexane) to give pure octa(cyclohexylsilsesquioxane) 1 (114 mg, 13\% yield).

1: colorless solid. ${ }^{1} \mathrm{H} \mathrm{NMR}\left(\mathrm{CDCl}_{3}\right): \delta=0.65-$ $0.85(\mathrm{~m}, 8 \mathrm{H}), 1.14-1.36(\mathrm{~m}, 40 \mathrm{H}), 1.60-1.88$ (m, $40 \mathrm{H}) \mathrm{ppm} .{ }^{13} \mathrm{C} \mathrm{NMR}\left(\mathrm{CDCl}_{3}\right): \delta=23.20,26.66$, 26.91, $27.51 \mathrm{ppm} .{ }^{29} \mathrm{Si} \quad \mathrm{NMR} \quad\left(\mathrm{CDCl}_{3}\right)$ : $\delta=-71.19 \mathrm{ppm}$. IR $(\mathrm{KBr}): v=2930,2860,1445$, $1270,1195,1110,1050,1025,895,845,825$, $735 \mathrm{~cm}^{-1}$. MS $(30 \mathrm{eV}): \mathrm{m} / z=1082\left(\mathrm{M}^{+}, 3 \%\right), 997$ (base), 915 (30\%), 833 (10\%).

\section{Reaction of dithexyldisiloxanetetraol and tetraphenyldisiloxanediol with dicyclohexylcarbodifimde}

The starting compounds were prepared by the reported methods. Dithexyldisiloxanetetraol ${ }^{4}$ $(0.44 \mathrm{~g}, \quad 1.1 \mathrm{mmol})$, tetraphenyldisiloxanediol ${ }^{12}$ $(0.31 \mathrm{~g}, 1.0 \mathrm{mmol})$ and dicyclohexylcarbodimide $(0.82 \mathrm{~g}, 4.0 \mathrm{mmol})$ were dissolved in $10 \mathrm{ml}$ DMSO and the solution was heated to $80^{\circ} \mathrm{C}$ for seven days. Water was added to the reaction mixture, which was extracted with ether. After drying and removal of the solvent, methanol was added to the residue, and $0.38 \mathrm{~g}$ of colorless solid was obtained. Separation with recycle-type HPLC (eluent: $\mathrm{MeOH} / \mathrm{THF}$,
9:1) gave 1,5-bis(1,1,2-trimethylpropyl)3,3,7,7,10,10-hexaphenylbicyclo[3.3.3]pentasiloxane $2(0.14 \mathrm{~g}, 24 \%)$ and 1,7-bis(1,1,2-trimethylpropyl)-3,3,5,5,9,9,11,11-octaphenyl[5.5.1]hexasiloxane $3(0.090 \mathrm{~g}, 17 \%)$.

$\mathrm{Ph}_{6} \mathrm{Thex}_{2} \mathrm{Si}_{6} \mathrm{O}_{7}$ 2: colorless solid, mp 116-119 ${ }^{\circ} \mathrm{C} .{ }^{1} \mathrm{H}$ NMR $\left(\mathrm{C}_{6} \mathrm{D}_{6}\right): \delta=1.04(\mathrm{~d}, J=7.0 \mathrm{~Hz}, 12 \mathrm{H})$, $1.27(\mathrm{~s}, 12 \mathrm{H}), 1.89$ (sept, $J=6.7 \mathrm{~Hz}, 2 \mathrm{H}), 7.02$ (t, $J=7.6 \mathrm{~Hz}, 6 \mathrm{H}), 7.12(\mathrm{t}, J=7.6 \mathrm{~Hz}, 12 \mathrm{H}), 7.63(\mathrm{~d}$, $J=7.6 \mathrm{~Hz}, 12 \mathrm{H}) \mathrm{ppm} .{ }^{13} \mathrm{C} \mathrm{NMR}\left(\mathrm{C}_{6} \mathrm{D}_{6}\right): \delta=19.04$, $21.68,25.02,35.02,128.29,130.15,134.46$, $134.95 \mathrm{ppm} .{ }^{29} \mathrm{Si}$ NMR $\left(\mathrm{C}_{6} \mathrm{D}_{6}\right): \quad \delta=-21.39$, $-58.79 \mathrm{ppm}$. IR ( $\mathrm{NaCl}$ plate) $: \gamma=2955,1450$, 1150, $1080 \mathrm{~cm}^{-1}$. MS $(30 \mathrm{eV}): \mathrm{m} / z=783$ $\left(\mathrm{M}^{+}-\right.$Thex, 100\%), 713 (75\%).

$\mathrm{Ph}_{8} \mathrm{Thex}_{2} \mathrm{Si}_{6} \mathrm{O}_{7}$ 3: colorless solid, mp 243$246{ }^{\circ} \mathrm{C} .{ }^{1} \mathrm{H}$ NMR $\left(\mathrm{CDCl}_{3}\right): \delta=0.69(\mathrm{~d}, J=6.7 \mathrm{~Hz}$, $12 \mathrm{H}), 0.72$ (s, 12H), 1.49 (sept, $J=6.7 \mathrm{~Hz}, 2 \mathrm{H}$ ), $6.82(\mathrm{t}, J=7.3 \mathrm{~Hz}, 6 \mathrm{H}), 7.10(\mathrm{t}, J=7.6 \mathrm{~Hz}, 3 \mathrm{H})$, $7.17(\mathrm{t}, J=7.6 \mathrm{~Hz}, 6 \mathrm{H}), 7.29(\mathrm{dd}, J=7.3,6.7 \mathrm{~Hz}$, $9 \mathrm{H}), 7.47(\mathrm{~d}, J=6.7 \mathrm{~Hz}, 6 \mathrm{H}) \mathrm{ppm} .{ }^{13} \mathrm{C}$ NMR $\left(\mathrm{CDCl}_{3}\right): \delta=18.42,20.00,24.32,33.12,127.42$, 127.47, 129.68, 129.94, 133.81, 134.26, 134.41, $135.15 \mathrm{ppm} .{ }^{29} \mathrm{Si} \quad \mathrm{NMR} \quad\left(\mathrm{CDCl}_{3}\right): \delta=-24.4$, $-65.8 \mathrm{ppm}$. IR (NaCl plate): $v=3100,2955,1450$, 1150, 1095, $1055 \mathrm{~cm}^{-1}$. MS $(30 \mathrm{eV}): \mathrm{m} / z=981$ $\left(\mathrm{M}^{+}-\right.$Thex, 25\%), 259 (base).

\section{X-ray crystallographic analysis of 3}

A crystal specimen of dimensions $0.20 \mathrm{~mm} \times 0.20 \mathrm{~mm} \times 0.10 \mathrm{~mm}$ was mounted on a glass fiber, and used for data collection on a Rigaku AFC7S diffractometer using graphitemonochromated $\mathrm{Cu} \mathrm{K}_{\alpha}$ radiation. Cell parameters were refined by the least-squares method using 25 reflections in the range $53.22^{\circ}<2 \theta<56.13^{\circ}$. Intensity data were collected at $2 \theta<120.2^{\circ}$ by the $\omega-2 \theta$ scan technique at $20 \pm 1{ }^{\circ} \mathrm{C}$. Based on a statistical analysis of intensity distribution, and the successful solution and refinement of the structure, the space group was determined to be $P \overline{1}$. Of the 9156 reflections collected, 8745 were unique, and 3917 observed reflections $\left(\left|F_{O}\right| \geq 3 \sigma\left(F_{0}\right)\right)$ were obtained and corrected for Lorentz polarization and empirical absorption based on a $\psi$ scan. The structure was solved by SIR88. ${ }^{14}$ Non-hydrogen atoms were found from subsequent Fourier syntheses and refined anisotropically by the full-matrix least-squares method. Hydrogen atoms were included but not refined. Final $R$ and $R_{w}$ values are 0.072 and 0.065 , respectively. All calculations were 
carried out by teXsan ${ }^{15}$ with a SiliconGraphics INDY computer.

\section{Synthesis of 1,7-diphenyl-3,3,5,5,9, 9,11,11-octamethyl-2,4,6,8,10,13- hexaoxabicyclo[5.5.1]tridecasilane (4)}

Under a nitrogen atmosphere, tetramethyldisiloxanediol $^{16}(0.16 \mathrm{~g}, 1.0 \mathrm{mmol})$ and diethylamine $(0.29 \mathrm{~g}, 4.0 \mathrm{mmol})$ were dissolved in $5 \mathrm{ml}$ of benzene. Diphenyltetrachlorodisiloxane ${ }^{17}(0.18 \mathrm{~g}$, $0.50 \mathrm{mmol}$ ) in $5 \mathrm{ml}$ of benzene was added dropwise at room temperature. The mixture was stirred for an additional $5 \mathrm{~h}$, and $5 \mathrm{ml}$ of hexane was added. The salt generated was removed by filtration and the solvent was removed. Hexane $(2 \mathrm{ml})$ and benzene $(3 \mathrm{ml})$ were added to the residue and the mixture was passed through a silica-gel column. After concentration, the resultant mixture was purified with recycle-type HPLC (eluent: $\mathrm{MeOH} / \mathrm{THF}, 9: 1$ ) to give the product $(62 \mathrm{mg}, 22 \%)$.

$\mathrm{Me}_{8} \mathrm{Ph}_{2} \mathrm{Si}_{6} \mathrm{O}_{7} 4$ : colorless solid, mp 78-79 ${ }^{\circ} \mathrm{C}$. ${ }^{1} \mathrm{H}$ $\operatorname{NMR}\left(\mathrm{CDCl}_{3}\right): \delta=0.14(\mathrm{~s}, 12 \mathrm{H}), 0.32(\mathrm{~s}, 12 \mathrm{H}), 7.15$ (br s, 4H), $7.18(\mathrm{dd}, J=7.3,6.7 \mathrm{~Hz}, 2 \mathrm{H}), 7.90(\mathrm{dd}$, $J=7.3, \quad 6.7 \mathrm{~Hz}, 4 \mathrm{H}) \mathrm{ppm} .{ }^{13} \mathrm{C}$ NMR $\left(\mathrm{CDCl}_{3}\right)$ : $\delta=0.72, \quad 0.86, \quad 128.29, \quad 130.56, \quad 133.34$, $134.28 \mathrm{ppm} .{ }^{29} \mathrm{Si} \quad \mathrm{NMR} \quad\left(\mathrm{CDCl}_{3}\right): \delta=-17.31$, $-76.43 \mathrm{ppm}$. IR ( $\mathrm{NaCl}$ plate): $v=3150,3010$, 1440, 1280, 1145, 1090, $805 \mathrm{~cm}^{-1}$. MS $(30 \mathrm{eV})$ : $m / z=539\left(\mathrm{M}^{+}-\mathrm{Me}, 100 \%\right), 135(88 \%)$.

\section{X-ray crystallographic analysis of 4}

A crystal specimen of dimensions $0.40 \mathrm{~mm} \times$ $0.10 \mathrm{~mm} \times 0.10 \mathrm{~mm}$ was mounted on a glass fiber, and used for data collection on a Rigaku AFC7S diffractometer with graphite-monochromated $\mathrm{Cu}$ $\mathrm{K}_{\alpha}$ radiation. Cell parameters were refined by the least-squares method using 25 reflections in the range $20.85^{\circ}<2 \theta<56.13^{\circ}$. Intensity data were collected at $2 \theta<120.1^{\circ}$ by the $\omega-2 \theta$ scan technique at $20 \pm 1{ }^{\circ} \mathrm{C}$. Based on a statistical analysis of intensity distribution, and the successful solution and refinement of the structure, the space group was determined to be $C 2 / c$. Of the 2463 reflections collected, 2341 were unique, and 769 observed reflections $\left(\left|F_{0}\right| \geq 3 \sigma \quad\left(F_{0}\right)\right)$ were obtained and corrected for Lorentz polarization and empirical absorption based on a $\psi$-scan. The structure was solved by SHELXS86. ${ }^{18}$ Non-hydrogen atoms were found from subsequent Fourier syntheses and refined anisotropically by the full-matrix least- squares method. Hydrogen atoms were included but not refined. Final $R$ and $R_{w}$ values are 0.073 and 0.055 , respectively. All calculations were carried out by teXsan ${ }^{15}$ with a SiliconGraphics INDY computer.

\section{Reaction of dithexyldisiloxanetetraol and tetraphenyldisiloxanediol with dicyclohexylcarbodiimde at $120^{\circ} \mathrm{C}$}

The procedure was similar to the experiment at $80^{\circ} \mathrm{C}$. From dithexyldisiloxanetetraol $(0.87 \mathrm{~g}$, $2.1 \mathrm{mmol})$, tetraphenyldisiloxanediol $\quad(0.63 \mathrm{~g}$, $2.0 \mathrm{mmol})$ and dicyclohexylcarbodiimide $(1.72 \mathrm{~g}$, $8.3 \mathrm{mmol})$ in $20 \mathrm{ml}$ of DMSO, $0.060 \mathrm{~g}(10 \%)$ of 2 was obtained.

\section{Reaction of dithexyldisiloxanetetraol and tetraphenyldisiloxanediol with di- isopropylcarbodi-imide}

Dithexyldisiloxanetetraol $(0.31 \mathrm{~g}, 0.75 \mathrm{mmol})$, tetraphenyldisiloxanediol $(0.22 \mathrm{~g}, 0.70 \mathrm{mmol})$ and diisopropylcarbodi-imide $(0.39 \mathrm{~g} 3.1 \mathrm{mmol})$ were dissolved in $5 \mathrm{ml}$ DMSO and the solution was heated to $120^{\circ} \mathrm{C}$ for three days. Methanol was added to the reaction mixture and $0.37 \mathrm{~g}$ of colorless solid was obtained. Separation with recycle-type HPLC (eluent: $\mathrm{MeOH} / \mathrm{THF}$, 9:1) to give 1,3,7,9-tetrakis(1,1,2-trimethylpropyl)-5,5,11, 11-tetraphenyltricyclo[5.5.1.1 ${ }^{3,9}$ ]hexasiloxane $\mathbf{5}$ $(0.070 \mathrm{~g}, 23 \%)$.

$\mathrm{Ph}_{4} \mathrm{Thex}_{4} \mathrm{Si}_{6} \mathrm{O}_{8}$ 5: colorless solid, m.p. 320-324 ${ }^{\circ} \mathrm{C} .{ }^{1} \mathrm{H}$ NMR $\left(\mathrm{C}_{6} \mathrm{D}_{6}\right): \delta=0.75(\mathrm{~d}, J=6.7 \mathrm{~Hz}, 24 \mathrm{H})$, $0.78(\mathrm{~s}, 24 \mathrm{H}), 1.54(\mathrm{sept}, J=6.7 \mathrm{~Hz}, 4 \mathrm{H}), 7.23(\mathrm{t}$, $J=7.6 \mathrm{~Hz}, 8 \mathrm{H}), 7.28(\mathrm{t}, J=7.6 \mathrm{~Hz}, 4 \mathrm{H}), 7.58(\mathrm{~d}$, $J=7.6 \mathrm{~Hz}, 8 \mathrm{H}) \mathrm{ppm} .{ }^{13} \mathrm{C} \mathrm{NMR}\left(\mathrm{C}_{6} \mathrm{D}_{6}\right): \delta=18.53$, $20.59,24.18, \quad 34.12,127.45,129.80,133.92$, $135.20 \mathrm{ppm} .{ }^{29} \mathrm{Si} \quad \mathrm{NMR} \quad\left(\mathrm{C}_{6} \mathrm{D}_{6}\right): \quad \delta=-43.65$ $-60.40 \mathrm{ppm}$. IR $(\mathrm{NaCl}$ plate): $\gamma=2955,1450$, 1100, $780 \mathrm{~cm}^{-1}$. MS $(30 \mathrm{eV}): \quad \mathrm{m} / \mathrm{z}=858$ $\left(\mathrm{M}^{+}-\right.$Thex, 100\%), $788(39 \%)$.

Acknowledgements The present study is partially supported by the REIMEI Research Resources of Japan Atomic Energy Research Institute, and by a Grant-in-aid from the Ministry of Education, Science and Culture of Japan. We thank Shin-Etsu Chemical Co. Ltd and Toshiba Silicon Co. Ltd for financial support. 


\section{REFERENCES}

1. M. Unno, K. Higuchi, M. Ida, H. Shioyama, S. Kyushin, H. Matsumoto and M. Goto, Organometallics 13, 4633 (1994).

2. M. Unno, H. Shioyama, M. Ida and H. Matsumoto, Organometallics 14, 4004 (1995).

3. M. Unno, T. Yokota and H. Matsumoto, J. Organometal. Chem. 521, 409 (1996).

4. M. Unno, B. A. Shamsul, H. Saito and H. Matsumoto, Organometallics 15, 2413 (1996).

5. A. J. Barry, W. H. Daudt, J. J. Domicone and J. W. Gilkey, J. Am. Chem. Soc. 77, 4248 (1955).

6. F. J. Feher and T. A. Budzichowski, J. Organometal. Chem., 373, 153 (1989).

7. J. F. Brown Jr and L. H. Vogt Jr, J. Am. Chem. Soc. 87, 4313 (1965).

8. F. J. Feher, D. A. Newman and J. F. Walzer, J. Am. Chem. Soc. 111, 1741 (1989), and references cited therein.

9. J. F. Brown Jr, L. H. Vogt Jr, A. Katchman, J. W. Eustance, K. M. Kiser and K. W. Krantz, J. Am. Chem. Soc. 82, 6194 (1960).
10. R. H. Baney, M. Itoh, A. Sakakibara and T. Suzuki, Chem. Rev. 95, 1409 (1995).

11. F. J. Feher, T. A. Budzichowski, R. L. Blanski, K. J. Weller and J. W. Ziller, Organometallics 10, 2526 (1991).

12. H. Behbehani, B. J. Brisdon, M. F. Mahon and K. C. Molloy, J. Organometal. Chem. 463, 41 (1993).

13. V. E. Shklover, T. Y. Struchkov, N. N. Makarova and A. A. Zhdanov, Cryst. Struct. Commun. 9, 1 (1980).

14. M. C. Burla, M. Camalli, G. Cascarano, C. Giacovazzo, G. Polidori, R. Spagna and D. Viterbo, J. Appl. Crystallogr. 22, 389 (1989).

15. Crystal Structure Analysis Package, Molecular Structure Corporation, 1985 and 1992.

16. J. F. Hide, J. Am. Chem. Soc. 75, 2166 (1953).

17. T. C. Wu and C. A. Hirt, J. Organometal Chem. 11, 17 (1968).

18. G. M. Sheldrick, in: Crystallographic Computing 3, Sheldrick, G. M., Kruger, C. and Goddard, R. (eds), Oxford University Press, Oxford, 1985, pp. 175-189. 